\title{
LINKAGES BETWEEN BIOLOGICAL AND CULTURAL DIVERSITY FOR PARTICIPATORY MANAGEMENT: NEPAL'S EXPERIENCES WITH MAKALU-BARUN NATIONAL PARK AND BUFFER ZONE
}

\author{
SHREE GOPAL JHA \\ Ministry of Forest \& Soil Conservation, Kathmandu, Nepal
}

Proceedings of the South and Central Asian MAB Meeting of Experts on Environmental Conservation, Management and Research, Hikkaduwa, Sri Lanka 15-18 October 2002

Summary: The Makalu-Barun National Park and Buffer Zone (MBNP \& BZ) of eastern Nepal cover an area of $2,330 \mathrm{~km}^{2}$. The Park shares its borders with Sagarmatha National Park in the west and with the Qomolangma Nature Preserve of Tibet Autonomous Region of the Republic of China in the north. This protected area of Nepal and Tibet cover over $40,000 \mathrm{~km}^{2}$ of the most threatened but significant greater Mt. Everest ecosystem of the South Asian Region.

The Park area has rich cultural diversity complete with many diverse ethnic groups. Most of the households are economically poor and depend on subsistence agriculture, animal husbandry and diverse natural resources for livelihood. The threats to biodiversity in MBNP and BZ area are slash and burn cultivation on steep slopes, poaching, hunting, over-grazing, high dependency on natural resources, poverty and food deficits. In response to all this, the Makalu-Barun Conservation Area Project was first initiated in 1988 as a joint endeavour of HMG of Nepal, INGO - the Mountain Institute, local organizations and communities with the aim of promoting participatory approaches towards sustaining conservation efforts for longterm benefits. This project ultimately established the Makalu-Barun National Park in 1992 and the area surrounding the Park was declared as the Buffer Zone in 1999. The basic underlying approach of protection and management of the Park and Buffer Zone is biodiversity conservation through people participation without relying on military force. This paper highlights the implementation of the biodiversity conservation and management approaches through people participation in the MBNP and Buffer Zone. The paper also explores notable achievements and the effectiveness of partnerships of the HMG of Nepal, INGO and local communities in sustaining conservation efforts as well as in improving the livelihood of the local people.

\section{Introduction}

Nepal has placed $18.32 \%$ of its total area $\left(147,181 \mathrm{~km}^{2}\right)$ in protected status, out of which 2,330 km² (1.6 \%) of Makalu-Barun National Park and Buffer Zone (1,500 $\mathrm{km}^{2}$ in NP and $830 \mathrm{~km}^{2}$ in BZ) lie in eastern Nepal covering 10 VDC of Sankhuwasabha District and 2 VDC of Solukhambu District. The park area borders Qomolangma Nature Preserve of Tibet Autonomous Region of China in the north, Soune Danda Ridge on the south, Arun River on the east and Sagarmatha National Park on the west. This protected area of Nepal and China covers over $40,000 \mathrm{~km}^{2}$ of the Mt. Everest ecosystem of the South Asia Region. The park area is the only protected area in the country to encompass such a wide altitudinal range from $435 \mathrm{~m}$ 
to $8,463 \mathrm{~m}$, the Mt. Makalu (the fifth highest summit in the world). It covers all bioclimatic types from tropical to alpine within a short span of $40 \mathrm{~km}$ north to south. (Fig.1 \& Fig. 2).

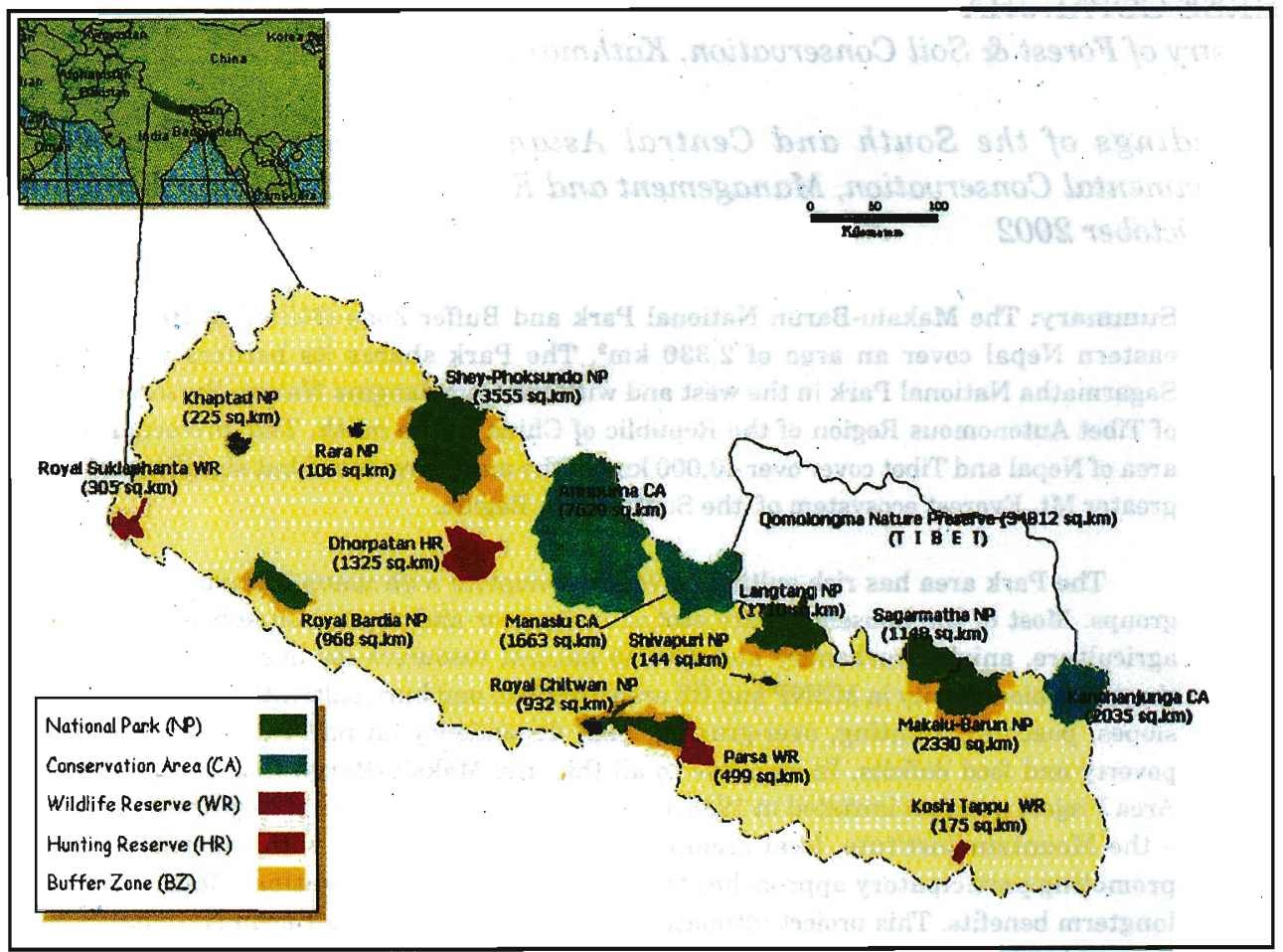

Figure 1: Protected Areas of Nepal

In the land mass, seven major watershed tributaries can be found, forming river valleys to the south (Barun, Kasuwa, Isuwa, Apswa and Sankhwa Rivers draining into Arun River, and Hongu and Inkhu River draining into Dudh Koshi River) (Fig. 3).

The Park area also has 9 lakes/ponds such as Panch Pokhari, Barun Pokhari, Tama Pokhari, Dudh Pokhari, Jhule Pokhari, Yekle Pokhari, Tin Pokhari, Thulo Pokhari, etc. It could be called the wettest area in the country as it receives the country's highest rainfall of over $4,000 \mathrm{~mm}$ per year.

About 35,000 people of diverse ethnic groups live in the area. The majority of the people in the area are Rai (64\%), while others comprise Bhote (18\%), Sherpa (8\%) and other castes/ethnic groups (10\%). The major languages are Rai, Tibetan, Sherpa and Nepali. Rais and other ethnic (Limbu, Kami Damai, Sarki, Brahaman, Chetre, and Magar) groups dominate the southern part of the lower valley slopes, 
whereas Tibetan Bhote Sharpa, Gurung, and Tamang, dominate the northern upland area. Most of the households consist of extremely poor, subsistence farmers who engage in marginal agriculture and livestock herding. Rotational slash and burn farming and animal husbandry are the main economic activities of the people. They also depend on diverse natural resources for livelihood. Many Shingsawa (Bhotia) and Sherpa families rear sheep, yak, goat, buffalo, etc. in the forest and pastoral land (Fig. 4)..

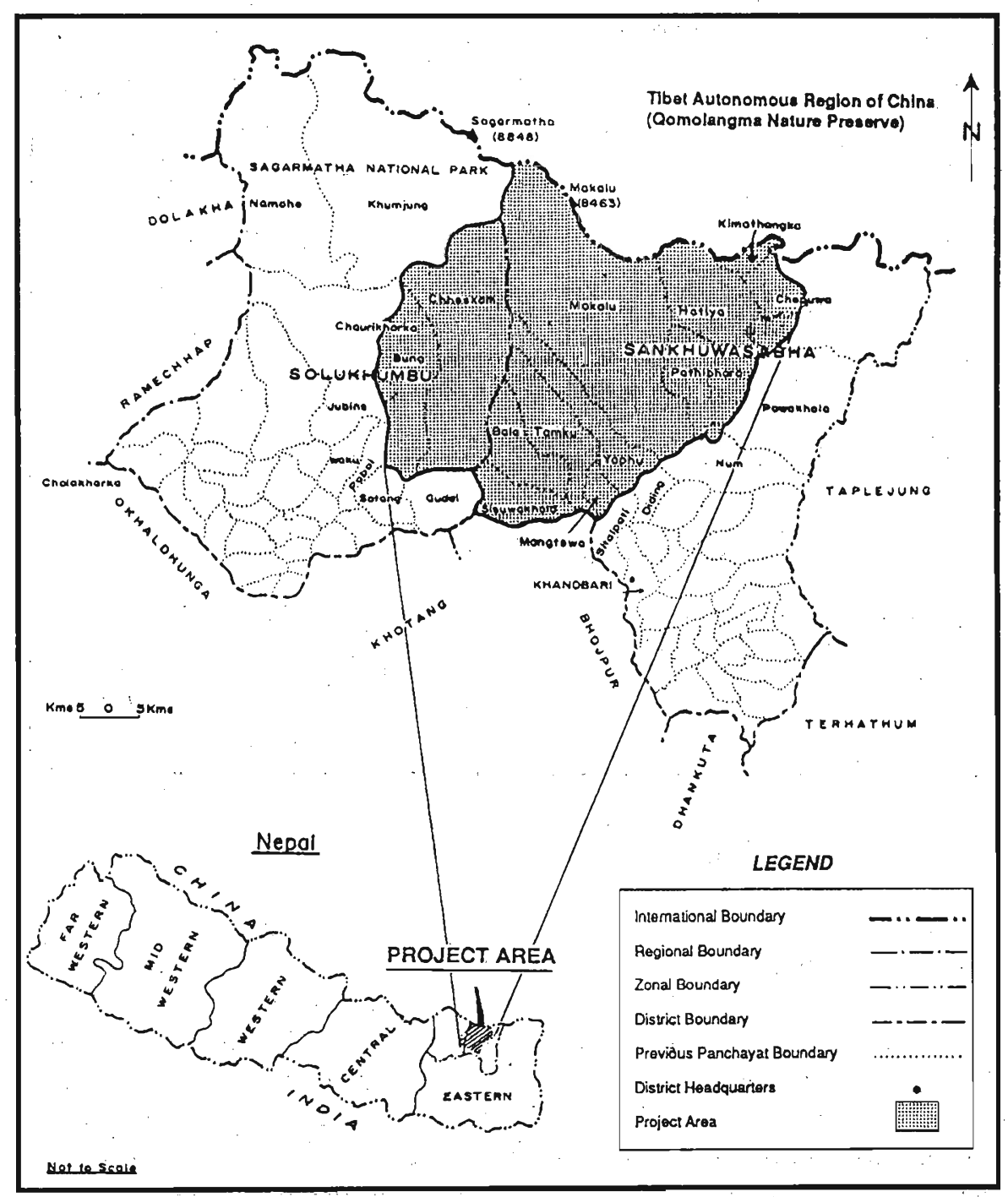

Figure 2: Location of the Project Area 


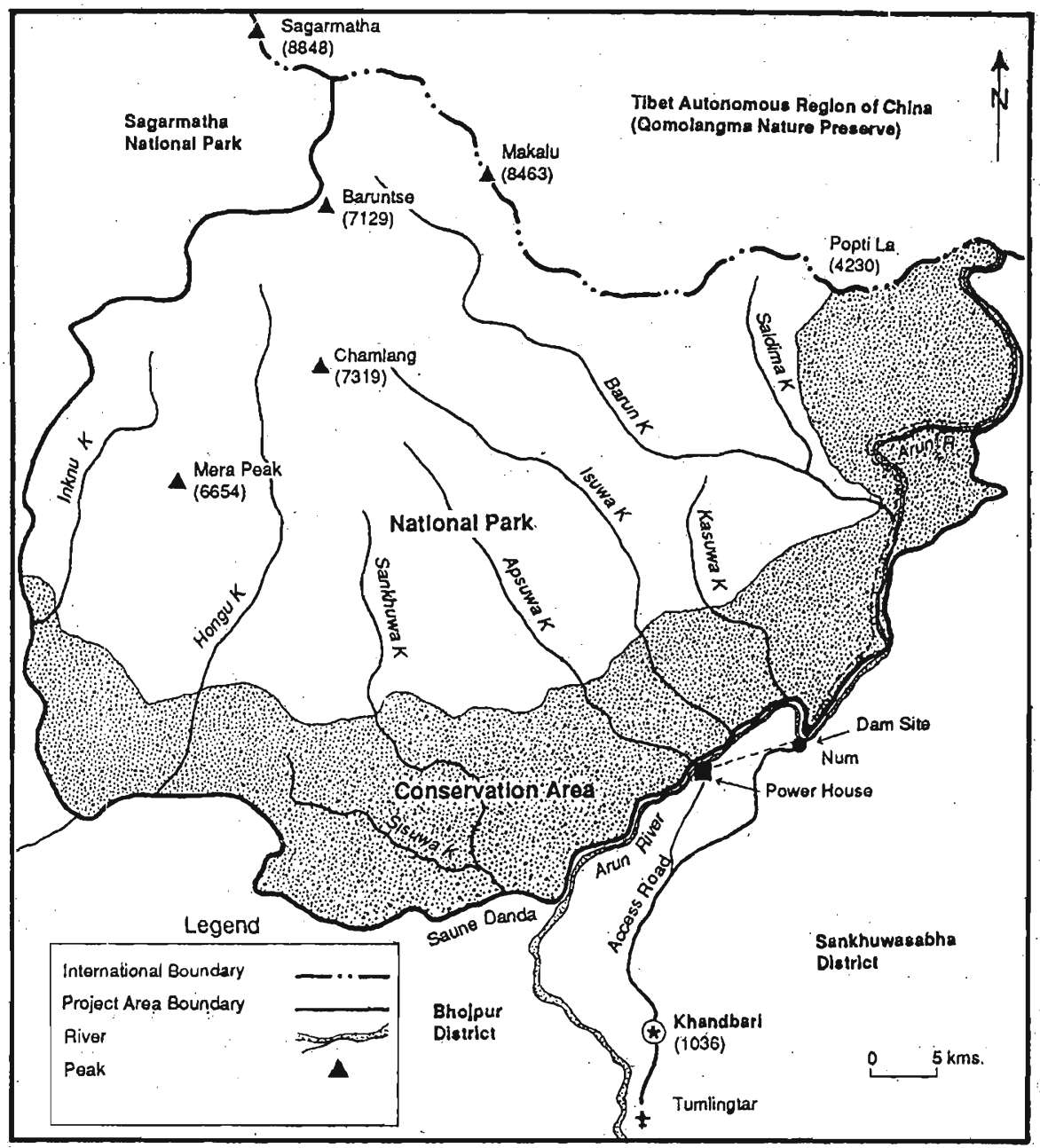

Figure 3: Project Area Base Map

Traditional and cultural heritages such as monuments, scriptures, sacred places like the Khembalung Cave, Saisma Monastery, Chyamtan and Syaksila Gomba, and various other shrines and paintings are being preserved, renovated and developed. Rai people worship both Hindu and Buddhist deites, whereas Sherpa and Tibetan Bhote follow Buddhism, and pray in the Gombas. In the Rai community, there are more than six Rai sub-tribes with different diction such as Kulung Rais, Mewahang Rais, Yamphu Rais and Majhikirat, etc. A custom of polyandrous marriage is followed by Karphote and Sherpa, near the Tibetan border.

MBNP and BZ are extremely rich in biological diversity. It harbours 27 types of forest with 3,128 species of flowering plants (which include 25 species of Rhododendron, 47 types of orchids, 48 types of wild rose, 87 species of medicinal 
and aromatic plants, 117 species of edible wild plants and 86 species of fodder). Of them, 56 are rare and threatened species. Similarly over 88 species of mammals are reported, including the Musk Deer, Red Panda, Snow Leopard, Clouded Leopard, Black Bear, Himalayan Thar and Ghoral. Likewise, 440 types of birds, 43 species of reptiles, 16 species of amphibians, 78 species of fish and 315 species of butterflies are reported.in the area.



Figure 4: Major Settlements

Due to exploitation of the forests for marginal agriculture and over-grazing, forest cover is being destroyed. Erosion and landslides are increasing, thereby decreasing the productivity of soil, pasture and forest. The park area also faces the 
problems of poaching, hunting, crop and livestock depletion, poverty and food deficit. In response to all this, the Makalu-Barun Conservation Area Project was initiated in 1988 as a joint endeavour of the Department of National Park and Wildlife Conservation, INGO - The Mountain Institute, local organizations and communities, with the aim of promoting participatory approaches towards sustaining conservation efforts for longterm benefits. This Project completed its feasibility study in 1992 and was turned into the Makalu-Barun National Park in 1992, and is implementing different activities from that year onwards. The conservation area surrounding the park was declared as the Buffer Zone in 1999.



Figure 5: Ecological Zones 
Makalu-Barun National Park is the only park in Nepal that does not use military force for its protection. Instead, it works together with the local people in the spirit of partnership to protect both the biological and cultural diversity of the area.



Figure 6: Makalu-Barun National Park and Buffer Zone Management Sector

Biological Diversity and its Cultural Linkage with the Various Ethnic Groups:

\section{(a) Biological diversity}

The present status of ecological zone-wise biodiversity of the Makalu-Barun area, which is being linked by the local tribe, is narrated in brief below (Fig. 5). 
Tropical Zone (435 - 1000 m.)

This zone is highly populated due to its warm climate and favorable topography. The principal tree species are Shorea robusta, and broad-leaved forest species like Schima spp., Castanopsis spp., Alnus spp., Albizia spp., Lagestroema spp., etc. Due to its proximity to human settlements, it is under great pressure. The wildlife in this zone includes Porcupine, Languor, Wild Boar, Jackal, etc. Rai, Limbu, Kami, Brahmin and Chetri and the main ethnic castes that are heavily dependant on the forest for timber, fodder, fuel wood and cattle grazing.

Sub Tropical Zone (1000 - 2000m.)

Though low in population density, this zone is still preferred by the various ethnic groups. The Rai, Limbu, Magar, Chetri and Brahman tribes dominate the area. Forest of Chirpine, Alnus, Allo (Gerardiana diversifolia), Schima - Castanopsis, bamboo spp. and other broad-leaved forests are present in this zone. Its wildlife includes the Clouded Leopard, Himalayan Black Bear, Jungle Cat, etc. Local tribes use the forest for fodder and firewood. Most of the ethnic groups in the area are highly dependent on bamboo spp. for construction purposes.

\section{Temperate Zone (2000 - 3000 m.)}

This zone is characterized by relatively dense forests of Rhododendron spp., Quercus spp., Maple, Daphne spp., Gerardinia diversifolia (Allo), Alder and Arundinaria (Malingo bamboo). There is sparse distribution of Arundinaria spp. in the areas, but in disturbed sites this species invades the entire area and makes it difficult to penetrate the forest. Important medicinal plants like Paris polyphylla, Kudki, Panchaule, Jatamansi, Padamchal, etc. grow there. Its wildlife includes Wolf, Musk Deer, Red Panda, Barking Deer and Himalayan Tahr. Rai, Sherpa, Gurung and Tamang, etc. use the forest for cattle grazing, as well as for fodder, firewood and medicinal plant collection.

Sub-alpine Zone (3000 - $4000 \mathrm{~m}$.)

The forest tree component of this zone includes forests of Rhododendron hodsonii, Betula utilis, Abis spectabilis, Juniperus recurva, etc. Also to be found are sub-alpine grass lands. Malingo bamboo is also widespread. On exposed areas are Berbaris spp., Cotoneastor spp., and Viburnum spp. It is mainly the Tibetan Bhote and Sherpa who use the forests for cattle herding and grazing in the summer, and collect important plants for trading. Its wildlife includes the Himalayan Weasel, Marmot, Yak, etc. Settlement of local people in this area is very low and in the winter the highland tribes move down to the low land. 
Alpine Zone (4000 - $5000 \mathrm{~m}$.

This zone is characterized by alpine grass lands, bushes, medicinal herbs, juniper, Rhododendron scrub in the low regions. The region above $5000 \mathrm{~m}$ comprises mainly of rock and ice with little vegetation, and wildlife limited to the endangered Snow Leopard and Red Fox, etc.

Nival (Above $5000 \mathrm{~m}$. )

This zone is an icy Himalayan area devoid of habitation.

\section{(b) Floral and faunal cultural linkages with the local tribes or communities}

Floral cultural linkage with the community: -

In the Makalu-Barun area, local people recognize and classify the plants that are available in and around the area, according to their various utilities and values. A wide range of resources has traditionally been gathered from the forest for food and other purposes. These include medicinal plants, fodder, edible plants, edible roots, wild honey; poison, etc. Many off-farm activities have been carried out in the MakaluBarun area either for home consumption or as a means of income generation. Eight species of Bamboo, 20 species of medicinal and aromatic plants, lokta paper (Daphne bholua) and Allo (Girardinia diversifolia) are the plants chiefly used by the local tribes. Kulung Rais women in particular use Allo fibre for making clothes, beautiful tight woven Ghums, jackets, bags, sacks, fishing nets and ropes such as Namalo and Damlo, Nanglo, etc. Besides Rais, Gurungs, Magars and other castes also produce clothes and other textile products as off-farm activites. The Kulunge Rais, Mehawang Rais and Sherpa men living in high altitudes are quite skilled at making bamboo and wooden crafts.

The knowledge of various utilities varies with age and sex. Men are more informed in areas such as timber, rituals and special uses of resources. Women possess indepth knowledge on plants that can be used for fodder, manure, edible species, etc. While ritual leaders like Shamans and Lamas possess indepth knowledge on the uses of plants for medicinal and ritual purposes, they are very reluctant to share that information with outsiders. They claim that such knowledge must not be shared with everyone unless a genuine cause can be given.

Faunal cultural linkage with community: -

Some of the fauna found in the Makalu Barun area are said to have medicinal and cultural values. Large bodied frogs, locally called "Paha", are eaten as a protein supplement. They are also used for medicinal purposes, with soup made of them being commonly given to children to cure sore throat. The skins of the monitor 
lizard are used for making musical instruments, its flesh and eggs are used in making medicine. Local wine prepared from the meat of the Jackal is said to be used for the treatment of tuberculosis and bath. The dried stomach of Porcupine, fresh blood of the Barking Deer and bile are said to be used to cure Asthma. It is believed that once taken, blood cures asthma patients for about 7 to 8 months. Unwanted pregnancies have been aborted by eating the fetus of the Barking Deer. The skin and Antlers of the Barking Deer are used to make the drums and drumsticks needed for ritual occasions. The meat of common birds like Myna, Crow and Indian Roller, are believed to be used to cure Piles. Body parts specially feet of Eagle, Cuckoo are used for making lockets and to control stomach - ache.

Besides such functional purposes, at a symbolic level too, many relations exist between the local community and animals. For example, chicken and pigs are used in many of the rituals of Tamangs, Magars and Rais. Rais need to use deers' legs when performing rituals at a person's death. They also sacrifice fish and small birds to liberate the dead from this earth. Without the sacrifice of such animals a funeral procession cannot proceed. The Mehwang Rai sacrifice birds, mainly Muste and Balse; during a feast to mark crop harvesting as well as to please the God Khawang. The Jimi Rai and Kulung Rais use the legs and skin of wild boar to burn incense (dhup). The Rai community also offers the liver and heart of different wild animals to ancestors and God. Thus cultural ritual practices of the Rai community have heavily contributed to poaching and hunting of wild animals. The Sherpa community which follows the Lama religion, seems to be religiously bound to protect wild animals, and is prohibited from sacrificing any animal. They only consume the meat of animals that have been sacrificed by Buddhist Sherpa not following the Lama religion. The sacrificed animal is worshipped and left for one full day before it is consumed. But such malpractices have reportedly decreased, after the establishment of the Makalu-Barun National Park and Buffer Zone.

\section{Threats to Biodiversity Conservation and Related Issues:}

\section{- Slash and burn cultivation}

This is widely practised in MBNP \& BZ, not only as a survival strategy, but also as a tradition. It is one of the main reasons for biodiversity degradation. The entire Makalu-Barun area faces food shortages, and many residents are deprived of sufficient food for as long as six months a year. Landless farmers seem to be particularly dependant on slash and burn cultivation in order to obtain food-grain (mostly millet) for themselves.

This system of cultivation involves the removal of old growth forests, thus causing loss to dependent faunal species. Furthermore, owing to the steep topography, the exposed soil, the area is especially vulnerable to erosion. It also increases the availability of herbaceous forage like agricultural crops, grasses, and 
shrubs, leading to an increase in the wildlife population and thereby increasing the conflict between man and animal. The fallow period is being shortened from traditional 12-year cycles to $4-5$ year cycles in order to get more food.

\section{- High cattle population and overgrazing}

Animal husbandry is a vital part of the economy of the local tribes in the study area. Almost every household usually keeps a large herd of animals to obtain manure, milk, and meat and to plough their fields. The average livestock population (cow, chauri, yak, buffaloes, goats, sheep and pig) per household in the area is as large as 15.2. People freely graze their livestock in the forests and on grasslands. Overgrazing leads to the loss of forest regeneration and grassland vegetation, thereby causing soil erosion and landslide problems.

\section{- High dependency on natural resources}

Energy utilization and NTFP/MAP collections are done in a traditional manner. For daily cooking, heating the room and for other domestic uses, most of the households in the area depend mainly on firewood collected from the forest. An average load of $25 \mathrm{~kg}$ (one Vari body load) of fuelwood is needed daily for each household. It is mostly the women in the family that collect fuelwood from nearby forests.

Because of forest degradation it requires a 3 to 4 hour walk to collect fuelwood. Free and uncontrolled firewood collection in the forest has destroyed many flora and fauna of the area. NTFP/MAP being common resources, people have a tendency of overexploiting them, in order to get a higher profit in a short period of time. They collect these plants prematurely and in a haphazard manner without the use of proper technical methods. This accounts for the decrease in resources.

\section{- Crop and livestock depletion by wildlife}

The extent of crop damage is high due to animals such as the Black Bear, Barking Deer and Wild Boar who raid crops at night. Crop depletion by wild animals is at its highest during the months of July, August and September, as this is the time when corn and millet ripen. In areas where the slash and burn agriculture system is extensive, crop depletion is also increasing. Apparently, crop raiding is higher in fields surrounded by scrubland and forests than in areas surrounded by other agricultural land, grassland, settlements etc. Leopards, wolves and bears are the main predators that kill a high number of livestock. Wolves usually kill small sized livestock such as goat and sheep. They are reported to kill as many as 12 animals at a time. On several occasions as many as 20 Wolf Scats were recorded in the MBNP and $\mathrm{BZ}$ area, on mountain ridges and along trails. Livestock loss is higher in winter when the animals are brought down to the village from the high altitude pasture, as 
the predator population is greater in the forests at lower elevations $(1,500-2,750$ $\mathrm{m}$.). In the Tamaku, Hatiya and Senduwa sectors, more goats, pigs and sheep are killed as compared to other animals. Therefore predatory animals such as the black bear, leopard, and wild boar are strongly disliked by people. Every year, 3 - 4 cases of human injury caused by the Black Bear are recorded in MBNP and BZ. Many of them are as a result of a sudden confrontation with the animal when people were collecting forest resources like firewood and fodder. The Rais communities suggest hunting as an effective means of controlling crop and livestock depletion.

\section{- Hunting and Poaching}

Crop and livestock depletion, mostly in the buffer zone and the cattle grazing area of the National Park, have compelled hunting of bears, deer, wolves and wild dogs. Communities have developed their traditional trapping mechanism for hunting. Hunting of the Musk Deer and the Himalayan Black Bear bring much value. 50 grammes of Musk (obtained from two male deer) and the gall bladder of a bear fetch a high price that and can give a family the equivalent of a year's income. It is used as an aphrodisiac and for the manufacture of local medicine.

The different sub-tribes of the Rai community herdsmen increasingly trap or poach wildlife while passing from lower to high altitudes in the course of their herding cycle. They kill wildlife for ritual practices, religious purposes, to prepare local medicine and for trading purposes.

\section{Biodiversity Conservation Approaches Through People Participation}

In response to the threats to biodiversity conservation, the Makalu-Barun Conservation Area Project was initiated in 1988 as a joint endeavour of the Department of National Park and Wildlife Conservation, INGO - The Mountain Institute, local organizations and communities, with the aim of promoting a participatory approach towards sustaining biodiversity conservation and management for longterm benefits. The project divided the area into four management sectors viz, Hatya Sector (Hatya, Chepuwa and Hongong VDCs), Seduwa Sector (Yaphu, Seduwa and Hedangna (Pathibhara) VDCs), Tamaku Sector in the Sankhuwasabha District (Bala, Sisuwa, Mangtewa, and Tamaku VDCs), and Bung Sector in the Solukhambu district (Bung and Chheskam VDCs) (Fig. 6).

The collaborative project completed the feasibility study and the preparation of the participatory management plan of these four sectors from 1988 to 1992 , and since 1992 has been implementing different activities. The activities conducted in the park area in a joint participatory manner since 1992 are highlighted in a nutshell below. 


\section{- Community development}

(A) Infrastructure development: - The activities conducted in the Buffer Zone are water supply construction and maintenance, construction of a suspension bridge and wooden bridge, trail maintenance, School Support Programme for providing physical facilities in schools, Conservation Education Programme and the conducting of non-formal literacy classes in various VDC.

(B) Eco-tourism development: - The major objective is to promote quality tourism that does not harm the environment of the park area. In this component, the major activities conducted are: the establishment of kerosene depots in four sectors as an alternative to fuelwood for tourists, the preparation of a Tourism Management Plan, formation of hotel and tourism associations and the construction of a wildlife watch camp/ view tower, etc.

(C) Income-generation programme: - The major work concentrated in the Buffer Zone are: the promotion of off-farm activities (cloth weaving from Allo plant fiber, the making of craft and other products from bamboo), and its market development, promotion of rabbit farming, promotion of improved varieties of livestock farming (providing improved breeds of pigs, male goats, chicken, etc.), promotion of bee-keeping (providing improved beehives), skills development training to local people, etc.

\section{- Local culture conservation}

The park area is very rich in its cultural aspects, combining the local cultures of Rai, Sherpa and Bhote seems to add to its diversification. The major objective of the programme implemented under this component is to conserve local culture through the joint participation of local people. The major works carried out are: various Gomba construction/ maintenance work, construction of various temples, dharmasalas and sacred places, providing support to Gomba and temples in the form of cash grants.

\section{- Natural resource management}

(A) Community forestry programme: - The collaborative project focused on the handing over of all accessible forests to the concerned user group in the Buffer Zone area. Under this, the major activities conducted are: the formation of the community forestry user group, preparation of the operational plan, handing over of community forests to the concerned user group, forest resource assessment, different training given to community forestry user groups for community forest management, production and distribution of seedlings (for community, agro-forestry and private plantation), implementation of capacity building programmes for CFUG \& CBO, pre-formation support and post formation support to CFUG. 
(B) Grazing area management: - Overgrazing of livestock in the park area is considered a serious problem of management. Proper utilization and management of pastureland in the MBNP \& BZ, through peoples' participation, is the major objective of grazing area management. Under this component, the major activities implemented are: identification of pastureland inside the national park and determination of the carrying capacity of these lands, preparation of a grazing area management plan, formation of grazing area management user groups, preparation of an operational plan for grazing areas, etc.

\section{Notable Achievements and the Effectiveness of the Partnership Project for Improving Local Livelihood:}

- Under the small research grant programme, more than 30 research projects such as the study on different bird species, the socio-economic and cultural study, research on slash and burn cultivation, research on crop and livestock depletion from wildlife, study on NTFP/MAP, agroforestry research in the Buffer Zone area, study on fuelwood, fodder and grazing, study on off-farm activities and income-generation, study on fauna, flora and forests of MBNP area etc., have been completed on the park area. A series of recommendations has been given for the achievement of the Makalu Barun Conservation Project goal and objectives:

- It is the first National Park to be established without reliance on military force for its protection.

- It promoted a new model for protected area management that involved local people in every step of park management. Local people are encouraged to be involved in park patrolling and Buffer Zone related programmes and activities.

- The formation and strengthening of over 200 community based organizations $(\mathrm{CBOs})$ dealing with various issues such as income-generation activities, off-farm activities, women's rights and advocacy, wildlife depletion, cardamom plantation on community forests, etc.

- All CBOs have funds and they have also been trained in participatory natural resource management and livelihood improvement programmes. Funds are generated through membership dues, sales of forest products, grants from the projects, etc. An average group has around 20,000 Rupees. These funds are used for soft loans which have helped increase income levels of the local people.

- The project supported non-formal education literacy classes of 3 to 6 months duration, in all the management sectors of the park area that benefited over 1,500 local people. $95 \%$ of the beneficiaries of these programmes were women. 
- The Collaborative Conservation Project has supported over 250 smallscale community infrastructure development projects, such as providing a drinking water supply system that provided safe drinking water to 57 villages, improving irrigation, building or repairing 19 suspension and wooden bridges, improving $74 \mathrm{~km}$ of trails, supporting of over 80 primary and secondary schools for physical facilities and infrastructure development, and providing improved grain water mills for 21 villages. In all these, the beneficiaries provided upto $50 \%$ of total costs. $75 \%$ of households or 25,000 people in the Makalu-Barun area directly benefited from the project.

- Over 97 Community Forest User Groups have been formed which are managing over 11,500 ha of natural forests. This covers over $90 \%$ of households of the MBNP area.

- Establishment of eight forest nurseries, owned and operated by local farmers in the Makalu-Barun area that produced and distributed 59,000 seedlings and saplings of various species for reforestation programmes, covering 37 hectares of degraded community and private lands.

- The Grazing Area Management Programme of the Project identified 356 pasturelands in the park area and found the carrying capacity of these lands. 6 Grazing Area Management User Groups were formed and 4 Operational Plans for grazing areas were prepared.

- Conducted 75 different livelihood improvement training programmes for over 3,000 people, (such as sewing and cutting, Allo weaving and knitting, trekking, cook and lodge management, book-keeping, carpentry, bamboo craft and material production, etc), more than half of whom were women. This helped to improve 43 village lodges, increased vegetable production in 38 villages, created technical level jobs and generated supplementary incomes from the sales of bamboo and siru grass crafts for 96 households.

- The project supported the conservation of local culture by constructing and maintaining over 16 Gomba, 10 temples, 6 Dharmasalas and 4 Sacred places, etc. Concerned local communities have participated by donating up to $50 \%$ of the total cost in the form of physical labour and cash.

- An agreement was made for managing natural resources and eco-tourism across the Himalayan boundary as a result of transboundary exchanges between park managers from the Tibet Autonomous Region of China and Nepal, and thus promoting transboundary conservation cooperation between the two countries. Two participatory meetings were held in border villages that addressed the need for controlling cross border hunting and poaching, minimizing the transfer 
of livestock diseases, controlling the spread of forest fires, and improving livelihood through cross border tourism and trade, etc.

- Wildlife poaching and hunting are under control and there are several cases where poachers and hunters have been arrested with the help of the local community.

\section{References}

1. Bhatta L. D (1999). Makalu Barun National Park \& Conservation Area Project: Achievement since Inception of the Project.

2 Dhakal Suresh (2001). Socio-cultural Study of Makalu Barun Landscape Complex, submitted to the Nepal Bio-Diversity Landscape Project.

3 HMG/DNPWC/WMI (1990). The Makalu Barun National Park \& Conservation Area: Community Resource Management Component.

4 Kumar N. R. , Sangum K, Ramble C. (1990). The Makalu Barun National Park and Conservation area: Community Resource Management Component.

5 Sherpa L. N., Sherpa A., Shrestha J. (1990). The Makalu Barun National Park and Conservation Area: Park Management Component.

6 Singh, B. B. (2001). Socioeconomic Study of Makalu-Barun Landscape Complex. Final Report Submitted to the Nepal Biodiversity Landscape Project.

7 TMI/IUCN-Nepal (1995). Biodiversity of Makalu Barun National Park and Conservation Area. Applied Databases For Integrated Biodiversity Conservation in Nepal.

8 TMI, Royal Danish Embassy (1995). Biodiversity of Makalu Barun National Park and Conservation area: Tamku and Mangtewa VDCs (Tamku Sector). 